\title{
$\mathrm{GaN}$ 성장을 위한 기판의 Ion Implantation 전처리에 관한 연구
}

\author{
이재석 · 진정근 - 변동진 ${ }^{\dagger}$ - 이재상* - 이재형* · 고의 관** \\ 고려대학교 재료공학과 \\ *한국원자력연구소 \\ **기초과학지원연구원 서울분소
}

\section{Study of pretreatment with ion implantation on substrate for GaN}

\author{
J. Lee, J. Jhin, D. Byun ${ }^{\dagger}$, J.S. Lee*, J.H. Lee* and W.-K. Koh** \\ Department of Materials Science \& Engineering, Korea University \\ *Korea Atomic Energy Research Institute, P.O.Box 105 \\ ${ }^{* *}$ Seoul Branch, Korea Basic Science Institute
}

(2004년 6월 17일 받음, 2004년 7월 13일 최종수정본 받음)

\begin{abstract}
The structural, electrical and optical properties of GaN epilayers grown on various ion-implanted sapphire(0001) substrates by MOCVD were investigated. Sapphire substrates have been widely adopted to grow high quality GaN epilayer despite the large differences of lattice constant and thermal expansion coefficient between them. ${ }^{1)}$ So, GaN or AlN buffer layer and pre-treatment was indispensably introduced before the GaN epilayer growth. The ion-implanted substrate's surface had decreased internal free energies during the growth of the ions implanted sapphire(0001) substrates. The crystal and optical properties of GaN epilayers grown in ions implanted sapphire(0001) substrate were improved. Also, excessively roughened and modified surface by ions degraded the GaN epilyers. Not only the ionic radius but also the chemical species of implanted sapphire(0001) substrates could improve the properties of GaN epilayers grown by MOCVD. ${ }^{2)}$ This result implies that higher quality of $\mathrm{GaN}$ epilayers was achieved by using ion-implanted sapphire(0001) substrate with various ions.
\end{abstract}

Key words ion-implantation, GaN, MOCVD

\section{1. 서 론}

$\mathrm{GaN}$ 와 그에 관련된 질소화합물들은 청색 및 자외선 영 역의 light emitting diodes (LEDs)와 laser diode (LD) 같은 고온, 고전력 소자에 사용되기에 적합한 물리적, 화 학적 특성을 가지고 있다. ${ }^{3,4)} \mathrm{GaN}$ 의 wurzite 구조는 높 은 복사 경도(radiation hardness)에, 고효율 광전소자에 사용되기에 적합한 $3.4 \mathrm{eV}$ 의 직접 천이형 밴드갭을 가지 고 있다. 또한 이러한 구조는 완전한 이원계 화합물을 이 루게 되며, 같은 wurzite 구조를 가지고 밴드갭이 각각 $1.9,6.2 \mathrm{eV}$ 인 InN, AlN과 연속적인 고용체를 형성할 수 있게 해준다. ${ }^{5,6)}$

단결정 $\alpha-\mathrm{Al}_{2} \mathrm{O}_{3}$ 기판은 $\mathrm{GaN}$ 에피충과의 큰 격자 부 정합 및 열팽창계수의 차이에도 불구하고 $\mathrm{GaN}$ 에피층 을 성장시킬 때 쓰이는 가장 일반적인 기판이다. 그러나 $\mathrm{GaN}$ 와 사파이어 (0001) 기판과의 큰 부정합 때문에, 고 품질의 $\mathrm{GaN}$ 에피층을 성장시키기 위해서는 통상적으로

†E-Mail : dbyun@korea.ac.kr
낮은 온도에서 증착시키는 완충층이 필요하다.

질화 처리는 주로 $\mathrm{Al}_{2} \mathrm{O}_{3}$ 가 $\mathrm{AlN}$ 이나 $\mathrm{AlON}$ 으로 변하는 사파이어 표면의 화학적 변화로 설명할 수 있다. $800 \mathrm{eV}$ 주입 에너지와 $1 \times 10^{16} \mathrm{~cm}^{-2}$ 의 dose로 사파이어 $(0001)$ 기 판에 $\mathrm{N}^{+}$이온을 주입한 김과과 조 ${ }^{8)}$ 의 논문에서 안정된 $\mathrm{AlON}$ 와 $\mathrm{AIN}$ 상이 형성되는 것이 확인되었다.

이 연구에서는 $\mathrm{GaN}$ 에피층을 MOCVD (metal organic chemical vapor deposition) 법에 의해 성장 시, 그 sapphire 기판에 다양한 이온을 주입하여 전처리를 하였 을 때의 효과를 알아보았다. 이러한 이온 주입에 의한 sapphire(0001)기판의 화학적, 물리적 변화는 $\mathrm{GaN}$ 에피 층과 사파이어 $(0001)$ 기판 간에 열팽창 계수와 격자 상 수의 불일치에 의해 생기는 응력을 완화시켜 주게 된 다. 사파이어(0001) 기판 위에 $\mathrm{H}^{+}, \mathrm{He}^{+}, \mathrm{Ar}^{+}, \mathrm{As}^{+} . \mathrm{Xe}^{+}$ 이온들을 전처리 기술에 의해 인위적으로 각각 다른 에 너지, 다른 dose로 주입시켰다. 성장된 $\mathrm{GaN}$ 에피층의 특 성은 AFM, DCXRD, Hall Measurement, PL, RAMAN 등을 이용해 측정하였다. 우리는 다양한 이온을 사파이 어(0001) 기판에 주입해 고품질의 $\mathrm{GaN}$ 에피층의 성장 가 
능성을 시험해 보았다.

\section{2. 실험 방법}

$\mathrm{GaN}$ 에피총 성장 전에, 먼저 다양한 종류의 이온 $\mathrm{H}^{+}$, $\mathrm{He}^{+}, \mathrm{Ar}^{+}, \mathrm{As}^{+}, \mathrm{Xe}^{+}$을 사파이어 (0001) 기판 위에 주입 하였다. 급격한 표면의 손상을 방지하기 위해 높은 에너 지로 가속시켜서 이온을 주입하였다. 그러나 그로 인해 기판의 주입 영역에 응력장이 발생되었다. 그리고 도편 츠의 채널링을 최소화하기 위해 이온이 주입되는 방향과 기판을 $7^{\circ}$ 기울여 주사해 주었다. 각기 다른 에너지를 주 입한 사파이어(0001) 기판들의 projection range를 계산 하기 위해 SRIM2003 프로그램을 이용하였다. 이때, sputtering에 의한 효과는 무시하고 계산된 이온주입을 생 각하였다. 따라서 실제적으로 이온주입 공정에서 일어날 수 있는 이온주입에 대한 차이는 차후 관찰하기로 하였 다. 이온 주입에 관한 모든 사항은 Table 1 에 기재하였 다. 이온 dose는 $1 \times 10^{16} \mathrm{~cm}^{-2}$ 이고 이온 주입의 current density는 $5.56 \mu \mathrm{A} / \mathrm{cm}^{2}$ 이다.

이온 주입한 사파이어(0001) 기판은 TCE, acetone, methanol 같은 유기 용매로 조심스럽게 세척한 다음, $\mathrm{H}_{2} \mathrm{SO}_{4}: \mathrm{H}_{3} \mathrm{PO}_{3}=3: 1$ 의 용액으로 $160^{\circ} \mathrm{C}$ 에서 에칭하였다. 남은 산화층을 제거하기 위해 $10 \% \mathrm{HF}$ 용액으로 다시 에칭하여 주고, 증류수로 씻어낸 다음, 질소 가스로 말 려 주었다. 이러한 표면 세척 과정 후에, 전처리 사파이 어(0001) 기판들을 즉시 MOCVD 반응기의 susceptor에 장착시켰다.

GaN는 수평 MOCVD 반응기(VTS Corp., VCV403$\mathrm{MO}$ )에 압력을 $300 \mathrm{Torr}$ 를 유지하며 성장시컸다. $\mathrm{Ga}$ 과 N
Table 1. The implantation schedules of $\mathrm{H}^{+}, \mathrm{He}^{+}, \mathrm{Ar}^{+}, \mathrm{As}^{+}$and $\mathrm{Xe}^{+}$.

\begin{tabular}{cccc}
\hline \hline $\begin{array}{c}\text { Implanted } \\
\text { ion }\end{array}$ & $\begin{array}{c}\text { Implanted } \\
\text { energy (keV) }\end{array}$ & $\begin{array}{c}\text { Dose } \\
\text { (ions/cm } / \mathrm{cm}^{2}\end{array}$ & $\begin{array}{c}\text { Projection } \\
\text { range (A) }\end{array}$ \\
\hline $\mathrm{H}^{+}$ & 30 & $1 \times 10^{16}$ & 2240 \\
$\mathrm{He}^{+}$ & 30 & $1 \times 10^{16}$ & 1940 \\
$\mathrm{Ar}^{+}$ & 100 & $1 \times 10^{16}$ & 650 \\
$\mathrm{As}^{+}$ & 100 & $1 \times 10^{16}$ & 570 \\
$\mathrm{Xe}^{+}$ & 100 & $1 \times 10^{16}$ & 297 \\
\hline
\end{tabular}

의 소스로 각각 $\mathrm{TMG}$ (Trimethylgallium)와 암모니아 $\left(\mathrm{NH}_{3}\right)$ 를 사용하였고 이송 가스로는 수소 $\left(\mathrm{H}_{2}\right)$ 가스를 사 용하였다. 비교를 위해 이온 주입을 하지 않은 sapphire 기판도 같은 조건에서 성장시켰다. 열세척을 $\mathrm{H}_{2}$ 분위기, $1100^{\circ} \mathrm{C}$ 에서 10 분간 행한 후, 저온 $\mathrm{GaN}$ 완충층을 $550^{\circ} \mathrm{C}$ 에서 120 초간 $20 \mathrm{~nm}$ 두께로 성장시켰다. 그 다음, $3 \mu \mathrm{m}$ 두께의 $\mathrm{GaN}$ 에피층을 $1100^{\circ} \mathrm{C}$ 에서 60 분간 성장시켰다.

성장된 $\mathrm{GaN}$ 에피층의 구조적, 광학적 특성을 측정하 기 위해 DCXRD (double crystal x-ray diffraction), SEM (scanning electron microscopy), PL (photoluminescence)을 사용하였다.

\section{3. 결과 및 고찰}

Fig. 1 에서 $\mathrm{GaN}$ 에피층을 성장하기 전 사파이어(0001) 기판 위에 다양한 종류의 이온 $\mathrm{H}^{+}, \mathrm{He}^{+}, \mathrm{Ar}^{+}, \mathrm{As}^{+}$및 $\mathrm{Xe}^{+}$을 주입시킨 후 $\mathrm{AFM}$ 으로 표면을 분석하였다. 그림 에서 주입한 이온 반경이 커질수록 표면의 거칠기가 커 지는 것을 확인 할 수 있었고 이는 다른 연구 논문에

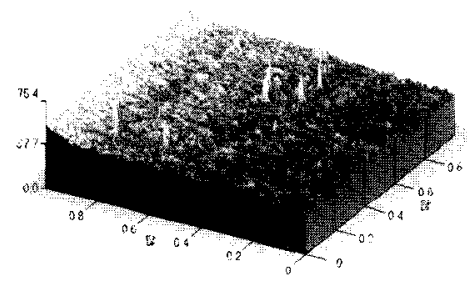

(a) Bare

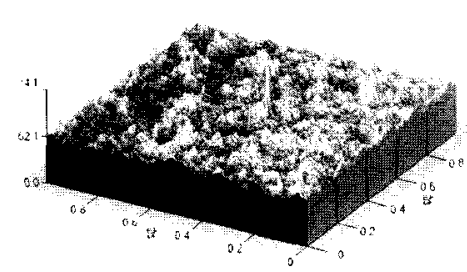

(d) Ar+

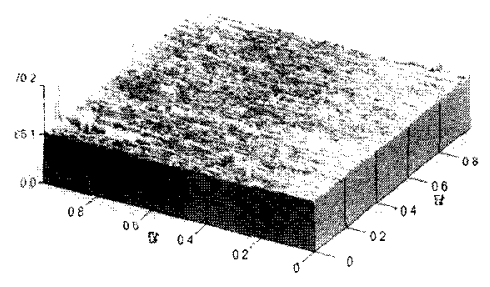

(b) $\mathrm{H}+$

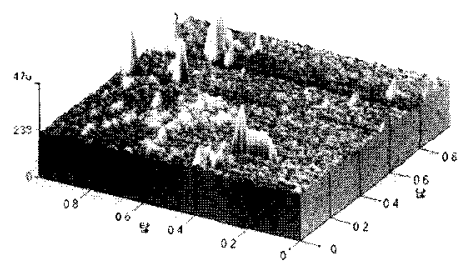

(e) As+

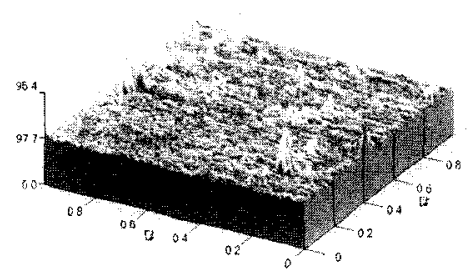

(c) $\mathrm{He}^{+}$

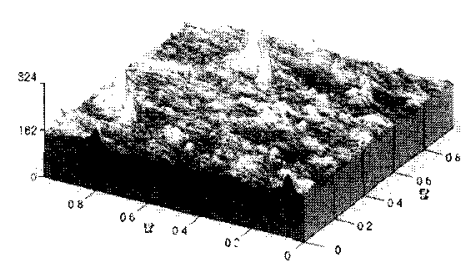

(f) $\mathrm{Xe}^{+}$

Fig. 1. AFM images of sapphire(0001) (a) non-implanted, (b) $\mathrm{H}^{+}$-ion implanted, (c) $\mathrm{He}^{+}$-ion implanted, (d) $\mathrm{Ar}^{+}$-ion implanted, (e) $\mathrm{As}^{+}$-ion implanted, (f) $\mathrm{Xe}^{+}$-ion implanted. 
서 보인 이온 주입을 통해 표면 거칠기가 증가하는 결 과와 일치하는 것을 볼 수 있다.2) 그에 따라 이온 주입 한 기판 내부에 응력이 발생했음을 예측할 수 있고 이 후 $\mathrm{GaN}$ 에피층을 성장시 박막에 영향을 끼친 것으로 판 단된다.

Fig. 2에서는 다양한 종류의 이온 $\mathrm{H}^{+}, \mathrm{He}^{+}, \mathrm{Ar}^{+}, \mathrm{As}^{+}$ 및 $\mathrm{Xe}^{+}$을 주입시킨 사파이어(0001)기판 위에 $\mathrm{GaN}$ 에피 층을 성장시킨 후 $\mathrm{AFM}$ 으로 표면을 분석한 것이다. 이 그림에서 보면 약 $4 \mu \mathrm{m}$ 정도의 두께로 성장 시킨 $\mathrm{GaN}$ 에피층의 표면 거칠기 변화는 거의 없었다. 이는 이온주 입 전처리를 통한 기판의 표면 거칠기 변화에 비하여 두 껍게 성장된 $\mathrm{GaN}$ 에피층으로 인한 표면 거칠기 변화의 차이는 거의 없었음을 보여주는 것이다. 이에 대한 다양 한 종류의 이온을 주입한 기판의 표면과 그 기판 위에 성장 시킨 $\mathrm{GaN}$ 에피층의 표면 거칠기를 비교하기 위하 여 Fig. 3에 AFM 측정을 통한 RMS (root mean square) 표면 거칠기 값을 나타내었다. Fig. 3에서 표면 거칠기 값은 이온 반경이 증가 할수록 점차 증가함을 볼 수 있 는데 이는 이미 예상된 결과로 이온 반경이 점차 커짐 에 따라서 기판에 높은 응력을 발생시키고 그와 함께 표 면에 보다 많은 영향을 끼쳤음을 알 수 있다. 즉, 이온 주입 전처리를 하지 않은 사파이어(0001) 기판의 경우 표 면에 거친 면은 나타나지 않지만, 이온주입 전처리가 된 기판의 경우 이온주입이 진행되면서 기판 표면이 완전히 변형되었음을 알 수 있다. $\mathrm{Xe}^{+}$의 경우는 다른 이온들 보 다 적은 에너지로 이온을 주입했기 때문에 표면의 많은 영향을 주지 않아 거칠기 값이 다소 감소한 것으로 보 인다.

Fig. 4는 각각의 이온 주입된 기판 위에 성장시킨 $\mathrm{GaN}$

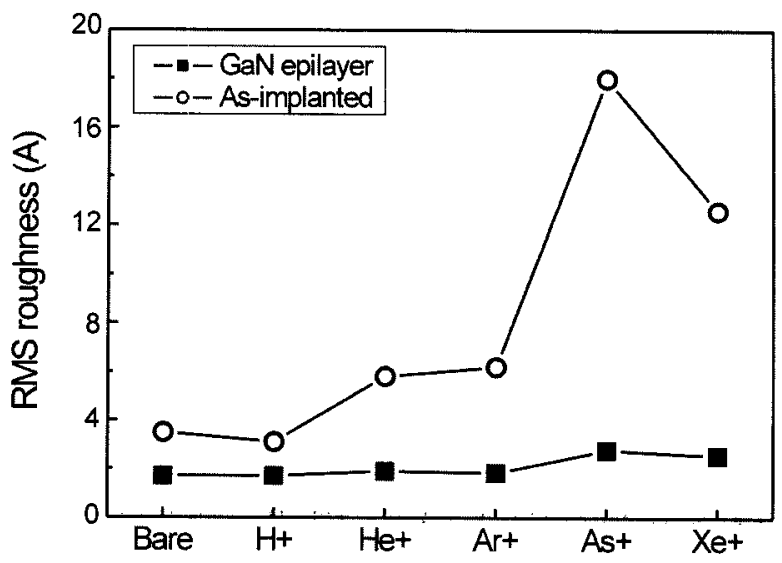

Fig. 3. RMS roughness of surface with as-implanted and $\mathrm{GaN}$ epilayer according to various ion-implanted sapphire(0001) substrate.

에피층의 측면 형상을 관찰하기 위하여 SEM을 측정한 것이다. 그림에서 이온 주입 전처리를 하지 않은 기판과 전처리를 행한 기판 위에 성장한 $\mathrm{GaN}$ 에피층의 측면을 관찰한 것이다. 이때의 조건은 동일한 온도와 압력, 5 족 13 족의 비로 약 $4 \mu \mathrm{m}$ 두께의 $\mathrm{GaN}$ 에피층을 성장시킨 것 이다.

Fig. 5는 사파이어(0001) 기판 위에 이온 주입을 통한 전처리 방법이 $\mathrm{GaN}$ 에피층의 결정성에 미치는 영향을 관찰하기 위하여 $\mathrm{DCXRD}$ 를 측정한 것이다. Fig. 5 는 이 온 주입을 하지 않은 기판과 이온 주입을 통한 전처리 기판 위에 각각 성장시킨 $\mathrm{GaN}$ 에피층의 $\mathrm{GaN}(0002)$ 피 크에서의 X-ray rocking curve와 FWHM (full width at half maximum)을 나타낸 것이다. 그림에서 볼 수 있듯

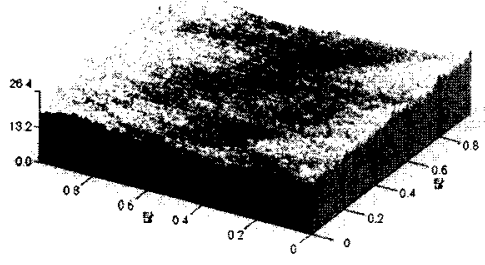

(a) Bare

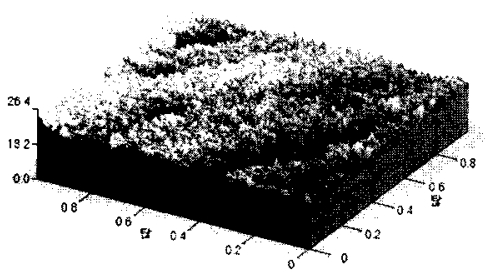

(d) $\mathrm{Ar}+$

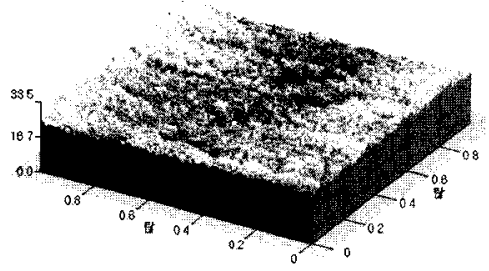

(b) $\mathrm{H}+$

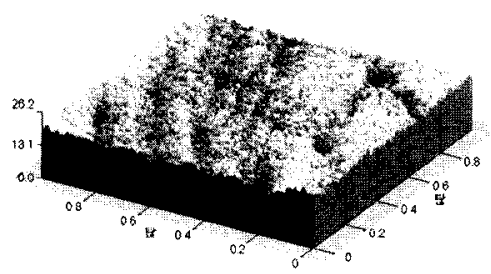

(e) $\mathrm{As}^{+}$

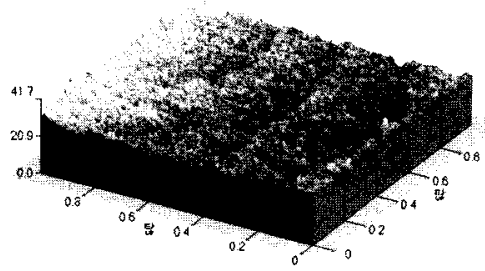

(c) $\mathrm{He}+$

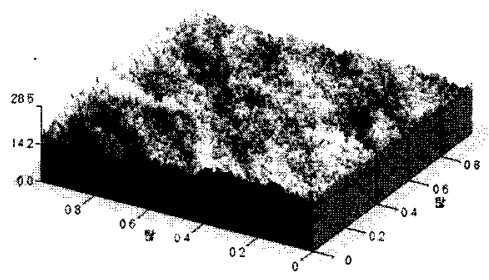

(f) $\mathrm{Xe}+$

Fig. 2. AFM images of GaN epilayers on sapphire(0001) (a) non-implanted, (b) $\mathrm{H}^{+}$-ion implanted, (c) $\mathrm{He}^{+}-$ion implanted, (d) $\mathrm{Ar}^{+}-$ ion implanted, (e) $\mathrm{As}^{+}$-ion implanted, (f) $\mathrm{Xe}^{+}$-ion implanted. 


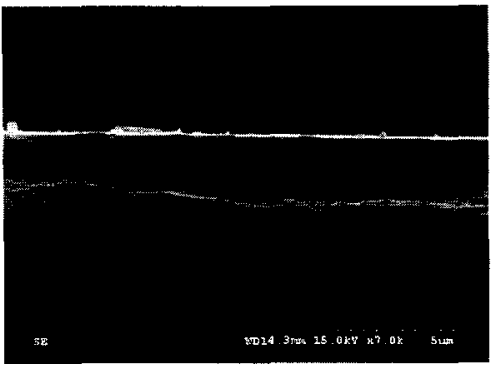

(a) Bare

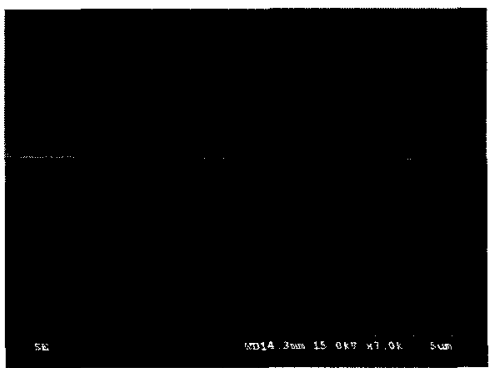

(d) $\mathrm{Ar}+$

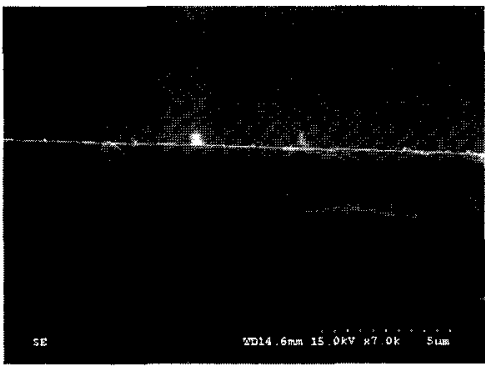

(b) $\mathrm{H}^{+}$

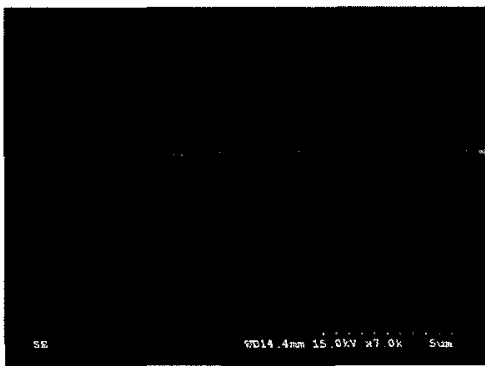

(e) As+

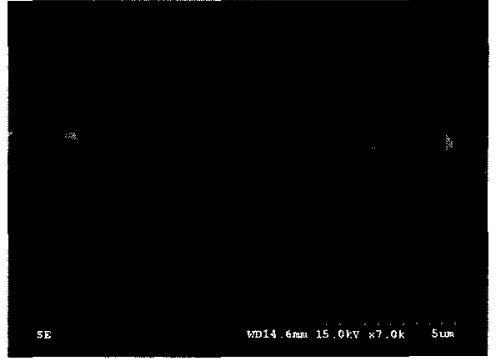

(c) $\mathrm{He}+$

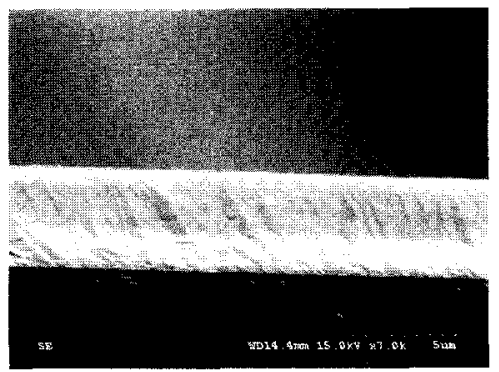

(f) $\mathrm{Xe}+$

Fig. 4. SEM cross section images of the GaN epilayers on various ion implanted sapphire (0001).

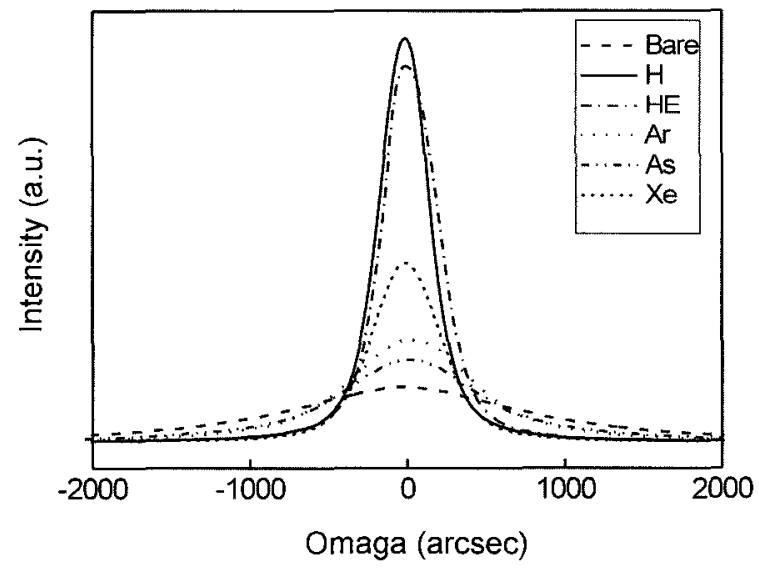

Fig. 5. X-ray rocking curve of the (0002) peak of $\mathrm{GaN}$ epilayer grown on various ion-implanted sapphire(0001) substrate. $(40 \mathrm{kV}, 20 \mathrm{~mA})$

이 이온 주입 전처리된 기판 위에 성장한 경우 이온 주 입하지 않은 기판 위에 성장한 경우보다 결정성이 향상 되었으며 특히 이온 반경이 작은 $\mathrm{H}^{+}$와 $\mathrm{He}^{+}$이온을 주 입 시켰을 때 가장 좋은 결정성을 나타내었고, 이온 반 경이 증가할수록 결정성이 떨어지는 것을 확인 할 수 있 었다. 이는 박막 내부에서 이온 주입을 통한 응력 분포 의 변화로 인해 기판과 $\mathrm{GaN}$ 박막의 계면 사이에서 완 충층의 역할이 이루어져 결정성이 향상되었다고 볼 수 있 다. 여기에서 $\mathrm{Xe}^{+}$의 경우는 $\mathrm{AFM}$ 측정결과에서 보인 $\mathrm{RMS}$ 표면 거칠기 값과 마찬가지로 다른 이온들 보다는
적은 에너지를 가지고 사파이어(0001) 기판에 주입되었 기 때문에 이온 반경에 비해 표면에 영향이 덜하여 나 타난 현상이라 할 수 있다. 또한 RMS 표면 거칠기 값 의 결과와 마찬가지로 이온 반경이 커질수록 결정성이 떨 어지는 것을 확인할 수 있었다. $\mathrm{GaN}$ 에피층의 촉면성 장을 위해서는 크기가 큰 2-D grain 들이 필요하고, 그 로 인하여 표면 거칠기가 증가하여 에피층 성장시 자유 에너지를 감소시킨다는 연구보고 ${ }^{9}$ 와 비교해 봤을 때 $\mathrm{GaN}$ 에피층의 측면성장을 촉진시키기 위해서는 어느 정도의 표면 거칠기가 증가여 크기가 큰 결정립들이 필요하고 그 결과로 표면 거칠기가 증가한 $\mathrm{H}^{+}$와 $\mathrm{He}^{+}$의 경우에 가장 좋은 결정성을 나타내고 있다.

다양한 이온이 주입된 사파이어(0001) 기판 위에 성장 시킨 $\mathrm{GaN}$ 에피층의 전기적 특성을 조사하기 위해 Hall 효과 측정을 실시 하였다. Fig. 6은 Hall mobility와 carrier concentration의 값을 나타낸 것이다. 그림에서 볼 수 있듯이 사파이어(0001) 기판 위에 $\mathrm{He}^{+}$이온을 주입 한 후 $\mathrm{GaN}$ 에피충을 성장시켰을 때 가장 높은 Hall mobility 와 가장 낮은 carrier concentration을 가짐을 알 수 있었다. 이는 이온 주입을 통한 기판의 표면 거칠기 증가로 인해 기판 내부의 자유에너지가 감소되었고, 또 한 $\mathrm{GaN}$ 에피층의 측면성장을 촉진 시키는 크기가 큰 2$\mathrm{D}$ grain 들이 형성되어 그로 인해 기판 내부의 응력 변 화가 에피충의 결정성을 향상시킨 결과와 일치하는 것을 볼 수 있었다.

한편 이온 주입된 사파이어(0001) 기판 위에 성장된 


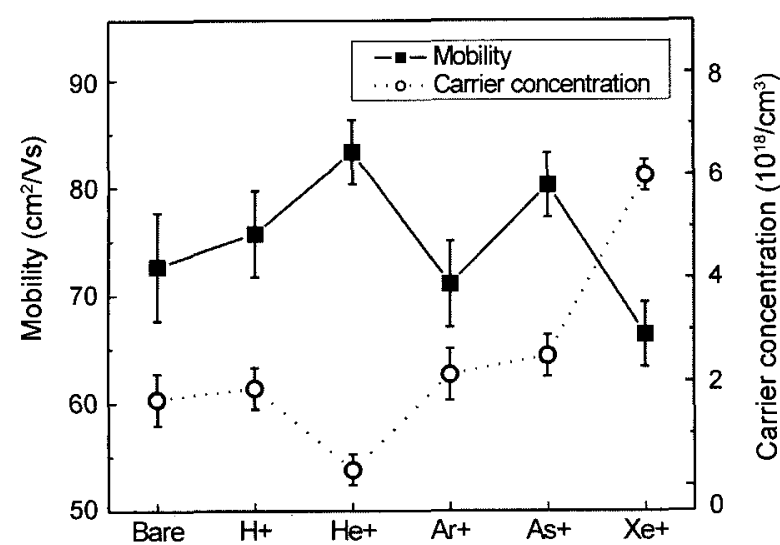

Fig. 6. Hall mobility and carrier concentration of $\mathrm{GaN}$ epilayer grown on various ion-implanted sapphire(0001) substrate.

$\mathrm{GaN}$ 에피층의 내부 잔류응력을 조사하기 위하여 Raman spectroscopy 측정을 하였다. 그림에서 Ref. 값은 사파이 어(0001) 기판 위에 HVPE (hydride vapor phase epitaxy) 방법으로 $300 \mu \mathrm{m}$ 두께로 성장된 $\mathrm{E}_{2}$ 포논 모드 값 $\omega\left(\mathrm{E}_{2}\right)$ $=567.8 \mathrm{~cm}^{-1}$ 인 GaN 에피충에서 측정된 Raman spectroscopy 값이다. 이 Ref. 값은 충분한 두께로 성장되어 있 기에 기판의 영향을 거의 받지 않아 내부의 잔류응력이 존재하지 않는다고 가정하여 실험에 의한 시료와의 비교 자료로 삼았다. 그리고 잔류응력의 시료간 차이를 알아 보기 위해 점군 $\mathrm{C} 6 \mathrm{v}$ 에 속하는 $\mathrm{GaN}$ 의 가장 강한 신 호인 $\mathrm{E}_{2}$ 포논에 대해서만 조사하였다. 보통 시료내의 잔 류응력의 크기는 기본 신호로부터의 변이크기에 선형적 으로 비례한다.

\section{$\mathrm{K}_{\lambda}=-4.51\left(\mathrm{~cm}^{-1} / \mathrm{GPa}\right) \sigma$}

여기에서 $\mathrm{K}_{\lambda}$ 는 포논 모드의 진동수와 변형력 간의 선 형 변형 인자이며, $\sigma$ 는 잔류응력을 나타낸다. ${ }^{10)} \mathrm{Fig} .7$ 에서 볼 수 있듯이, $\mathrm{He}^{+}$이온이 주입된 사파이어(0001) 기판 위에 성장된 $\mathrm{GaN}$ 에피층의 경우 가장 낮은 잔류 응력을 나타내고 있음을 알 수 있다. 이는 이온 주입된 사파이어(0001) 기판과 $\mathrm{GaN}$ 에피층 사이의 내부 변형 에 너지의 감소 효과로 인해 기인된 것으로 볼 수 있다.

이온 주입에 따른 $\mathrm{GaN}$ 에피층의 광학적 특성을 분석 하기 위하여 $15 \mathrm{~K}$ 에서 측정한 저온 PL측정 결과를 Fig. 8에 나타내었다. Hall 효과 측정 결과와 마찬가지로 $\mathrm{He}^{+}$ 이온을 사파이어(0001) 기판에 주입했을 때 가장 높은 통 합 강도 특성을 나타내는 것을 볼 수 있었다. 이것은 앞 의 $\mathrm{GaN}$ 에피층의 결정성을 확인한 $\mathrm{DCXRD}$ 결과와 내 부응력의 결과를 알 수 있는 Raman spectroscopy와 잘 일치하는 겻으로 $\mathrm{He}^{+}$이온이 주입되어 응력변형을 유도 한 경우에 가장 품질이 좋은 에피층이 성장되었다는 것

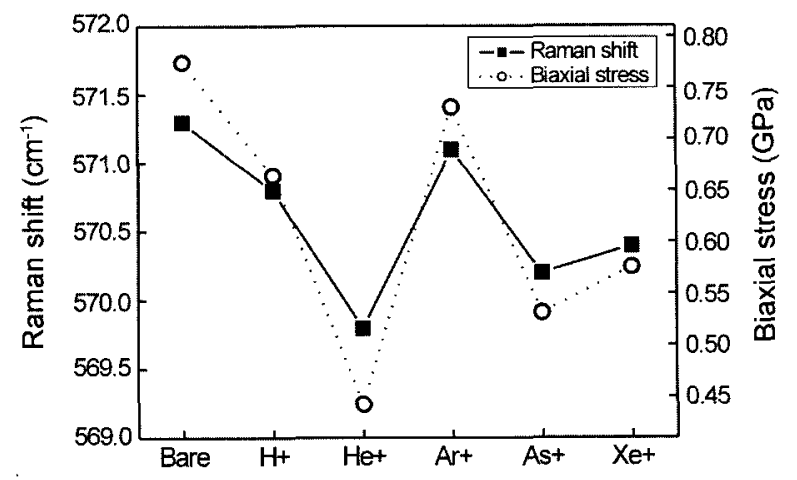

Fig. 7. Raman shift of the $E_{2}$ mode and biaxial stress in GaN epilayer grown on various ion-implanted sapphire $(0001)$ substrate

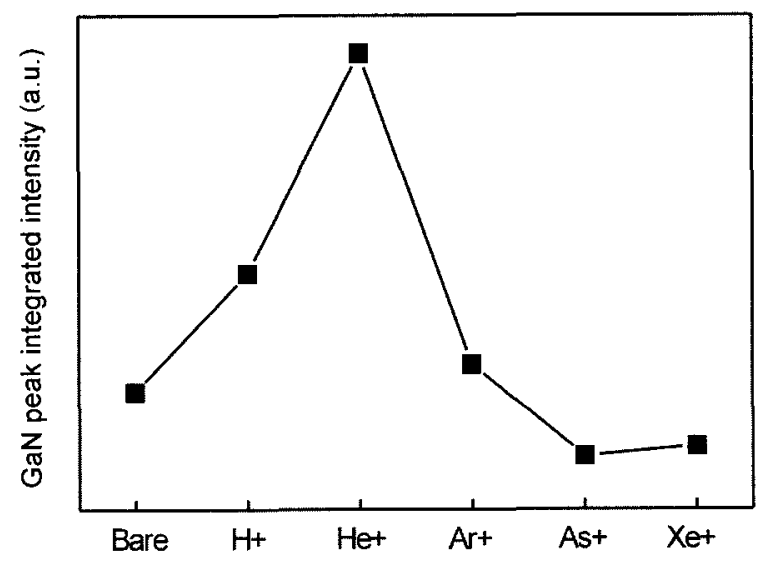

Fig. 8. PL spectra of GaN peak integrated intensity in GaN epilayer grown on various ion-implanted sapphire(0001) substrate.(RPM2000, $15.5 \mathrm{~mW}, 325 \mathrm{~nm}$ )

을 확인할 수 있다. 이를 통해 격자상수 차이가 많이 발 생하는 기판에 성장시키게 되는 $\mathrm{GaN}$ 에피층의 경우에 이온 주입을 통해 인위적으로 기판의 표면에 변형을 가 함으로써 보다 나은 물성의 박막을 얻을 수 있음을 학 인할 수 있었다.

\section{4. 결 론}

다양한 이온이 주입된 사파이어(0001) 기판 위에 MOCVD 법을 이용하여 성장시킨 $\mathrm{GaN}$ 에피충의 물성을 측정하였다. 이온 주입 시 이온 반경이 커짐에 따라서 사 파이어(0001) 기판 표면의 거칠기 값이 증가하였고, 그 에 따른 내부 응력이 발생했음을 확인하였다. 결정성이 가장 향상된 $\mathrm{He}^{+}$이온이 주입된 사파이어(0001) 기판 위 에 성장된 $\mathrm{GaN}$ 에피충의 경우와 마찬가지로 광학적 특 성을 나타내는 PL의 통합 강도 측정값도 가장 높게 나 왔다. 또한 Raman spectroscopy의 결과에서 알 수 있듯 
이 $\mathrm{GaN}$ 에피층에 존재하는 내부 응력의 값도 $\mathrm{He}^{+}$이 온이 주입된 기판 위에서 성장시켰을 때 가장 낮게 나 와 좋은 결과를 얼을 수 있었다.

고품질의 $\mathrm{GaN}$ 에피층을 성장하기 위한 여러 가지 공 정 중에서 우선 기판에 대한 전처리 공정이 매우 중요 하다고 할 수 있다. 이를 위해 $\mathrm{GaN}$ 에피층 내에 존재 하는 결함을 줄이기 위한 기존의 방법과는 달리 먼저 사 파이어(0001) 기판 표면을 다양한 이온들의 주입을 통하 여 표면처리를 한 후에 완충층을 사용하는 새로운 방법 으로 $\mathrm{GaN}$ 에피층의 전기적 특성, 광학적 특성 및 결정 성을 향샹을 나타내었다.

본 연구에서는 기타 다른 이은들의 이온 주입에 비해 $\mathrm{He}^{+}$이온이 주입된 사파이어(0001) 기판 위에 성장시킨 $\mathrm{GaN}$ 에피층의 경우에 가장 효과적인 응력 완화와 향상 된 결정성을 얻을 수 있었다.

\section{감사의 글}

본 연구는 2003 년도 산학협동재단의 지원을 받아 이 루어졌으며 이에 감사드립니다.

\section{참 고 문 헌}

1. J. Jhin, P. Kang, D. Byun, E.K. Koh, J.S. Lee, J.H. Lee, J. Korean Phys. Soc., 42, S345 (2003).

2. J. Kim, Y.J.Park, D. Byun, J. Jhin, M. Kang, E.K. KOH, Y. Moon and S.-K. Min, Jpn. J. Appl. Phys., 42, 3991 (2003).

3. S.C. Binari, L.B. Rowland, W. Kruppa, G. Kelner, K. Coverspike, D.K. Gaskill, Electron. Lett., 30, 1248 (1994).

4. S. Nakamura, T. Mikai, and M. Senoh, Appl. Phys. Lett., 64, 1687 (1994).

5. I. Akasaki and H. Amano, J. Electrochem. Soc., 141, 2266 (1994).

6. S. Strite and H. Morkoc, J. Vac. Sci. technol., B10, 1237 (1992).

7. H.-J. Kim, D. Byun, G. Kim and D.-W. Kum, J. Appl. Phys., 87, 7940 (2000).

8. Y. Cho, E. Koh, Y. Park, D. Koh, E. Kim, Y. Moon, S. Leem, G. Kim and D. Byun, J. Cryst. Growth, 236, 538 (2002).

9. D. L. Smith, Thin-Film Depositon : Principle and Practice, McGraw-Hill, New York, Chapter 5 (1992).

10. E. Koh, Y. Park, E. Kim, C. Park, S. Lee, J. Lee and S. Choh, J. Cryst. Growth, 218, 214 (2000). 